\title{
Metabolic Patterns in Acetic Acid Bacteria
}

\author{
BY K. E. COOKSEY AND C. RAINBOW \\ Department of Applied Biochemistry, University of Birmingham
}

(Received 4 May 1961)

\section{SUMMARY}

Evidence is presented that the distinction, already made on nutritional grounds, between lactaphilic and glycophilic strains of acetic acid bacteria may be traced back to the metabolic level. Thus, the capacity of cell extracts to effect reversible transamination from glutamate to aspartate was well developed in lactaphiles, but only feebly so, or not at all, in glycophiles. Again, suspensions of lactaphiles possessed greater general ability to oxidize intermediates of the tricarboxylic acid cycle than did those of glycophiles. Cell extracts of lactaphiles possessed citrogenase activity, which was not detected in glycophiles. The conversion of L-aspartate to $\alpha$-alanine by extracts of lactaphiles appeared to proceed by $\beta$-decarboxylation, not by transamination.

\section{INTRODUCTION}

Previous work (Rainbow \& Mitson, 1958; Brown \& Rainbow, 1956) indicated that acetic acid bacteria might be grouped, on nutritional and biochemical grounds, into lactaphiles and glycophiles. In seeking the metabolic basis of the observed differences, three aspects of the metabolism of five lactaphilic and four glycophilic strains of Acetobacter were studied: (a) the capacity of cell extracts to effect transaminations involving glutamate, aspartate and $\alpha$-alanine; (b) the capacity of suspensions of whole organisms to oxidize intermediates of the tricarboxylic acid (TCA) cycle; (c) the citrogenase activity of cell extracts.

\section{Materials}

\section{METHODS}

Substrates were commercial preparations of laboratory reagent grade, except succinic acid and sodium acetate, which were of analytical reagent grade. No ninhydrin-reacting impurities were detected when $180 \mu \mathrm{g}$. portions of the amino acids were chromatographed on Whatman No. 4 paper.

\section{Test organisms and cultivation}

Stock cultures of the test organisms were maintained as described by Rainbow \& Mitson (1953). The organisms were the strains of Acetobacter studied by those authors and the strains of Acetobacter ascendens and $A$. oxydans studied by Brown \& Rainbow (1956). However, the culture previously called $A$. suboxydans NCIB 7069 is referred to in this present paper as $A$. rancens which we now believe to be its correct name. Brown \& Rainbow (1956) drew attention to the anomalous position of their A. suboxydans strains as lactaphiles. Later, in a private communication to 
one of us (C. R.) Dr J. D. Shimwell (British Vinegars Ltd., Frome) pointed out that authentic cultures of $A$. suboxydans by definition do not oxidize acetate, and that the strains reported on from this laboratory might be wrongly labelled. This proved to be the case, for $\mathrm{Dr}$ Shimwell, who kindly examined our strains, reported that three strains labelled $A$. suboxydans (including NCIB 7069) were vigorous over-oxidizing Acetobacter spp.

For manometric work with suspensions of organisms, these were grown as described by Brown \& Rainbow (1956) except that the glycophiles were grown on the same lactate-containing medium as were the lactaphiles, in order to ensure as far as possible that differences in the enzyme make-up of the organisms were not ascribable to cultivation in different media. Organisms were harvested (centrifuge) after incubation for 3-5 days, washed three times (aseptic precautions) with $25 \mathrm{ml}$. portions of $0.85 \%(\mathrm{w} / \mathrm{v}) \mathrm{NaCl}$ and finally suspended in $0.05 \mathrm{M}$-phosphate buffer (pH 5-8). Optical densities of these suspensions were determined turbidimetrically by the Spekker photoelectric absorptiometer (Hilger, London) and the values thus obtained were related to cell dry matter by reference to curves previously constructed for each strain of Acetobacter. The suspensions were then diluted with buffer to an appropriate standard of cell dry matter.

For the preparation of cell extracts, organisms were grown and harvested as above, except that they were washed in $1.1 \%(\mathrm{w} / \mathrm{v}) \mathrm{KCl}$ solution, and they were finally suspended in about $8 \mathrm{ml}$. of ice-cold $0 \cdot 1 \mathrm{M}$-phosphate buffer (pH $5 \cdot 8$ ) before being disrupted.

Escherichia coli ATCC 4157 organisms, required as a source of coenzyme A and transacetylase in citrogenase experiments, were grown as described by Ochoa, Stern \& Schneider (1951). They were harvested and washed as described above.

\section{Experiments with suspensions of organisms}

Manometric measurements of the oxygen taken up at $3^{\circ}$ by washed whole organisms during the oxidation of organic acids were carried out by a conventional technique with the Warburg constant-volume respirometer.

\section{Experiments with cell extracts}

Cell extracts. These were prepared from the suspensions of acetobacters and Escherichia coli ATCC 4157 in phosphate buffer (see above) by mechanical disintegration with ballotini beads $(0 \cdot 2-0 \cdot 3 \mathrm{~mm}$. diam.) for $30 \mathrm{~min}$. under refrigerated conditions in a tissue disintegrator (H. Mickle, Gomshall, Surrey). After disruption, the suspension was washed from the beads with small portions (about $10 \mathrm{ml}$. in all) of ice-cold $0.05 \mathrm{M}$-phosphate buffer ( $\mathrm{pH} \mathrm{7 \cdot 3)}$. The resulting suspension was centrifuged at $0-2^{\circ}$ for $20 \mathrm{~min}$. at $20,000 \mathrm{~g}$ to yield a residue possessing little or no relevant enzymic activity, and a 'soluble enzyme' fraction. The latter was used for transaminase, aspartate decarboxylase and citrogenase experiments. The total nitrogen of this fraction was determined by the micro-Kjeldahl procedure, or its protein content was determined by the method of Lowry, Rosebrough, Farr \& Randall (1951).

Transaminase and $\beta$-decarboxylase activities. Evidence of these was sought through the production of new ninhydrin-reacting substances revealed by paper chromatography. In addition, aspartate $\beta$-decarboxylase activity was followed by con- 
ventional Warburg manometric measurement of the $\mathrm{CO}_{2}$ released at $25^{\circ}$ by cell extracts acting on L-aspartic acid at $\mathrm{pH} \mathbf{5 \cdot 2}$.

Citrogenase activity. This was tested by a slight modification of the procedure of Ochoa et al. (1951) which depends on the formation of citrate from acetyl phosphate and oxaloacetate in the presence of citrogenase, coenzyme $\mathbf{A}$ and transacetylase, the two last named being supplied as a cell extract of Escherichia coli ATCC 4157, which is itself deficient in citrogenase. Thus, those extracts of acetobacters capable of catalysing citrate synthesis from acetyl phosphate, oxaloacetate and the extract of $\boldsymbol{E}$. coli presumably did so by virtue of their citrogenase content. Under the conditions of the assay there was a linear relationship between enzyme concentration and citrate produced. Citrate was determined colorimetrically by the method of Macdonald \& Waterbury (1959). In our hands, there was a linear relationship between optical density at $445 \mathrm{~m} \mu$. and citrate content up to at least $100 \mu \mathrm{g}$.

\section{Chromatography}

Whatman No. 4 paper was used in conventional unidimensional descending or ascending technique.

For descending runs in transaminase experiments, two developing solvents were used : (a) $n$-butanol + acetic acid + water $(25+6+25, \mathrm{v} / \mathrm{v}) ;(b)$ phenol saturated with water. For the aspartic $\beta$-decarboxylase experiments, descending runs in solvent (a) and ascending runs in ethanol + ammonia (sp. gr. $0 \cdot 880)+$ water $(90+5+5, v / v)$ were applied. Amino acids were detected by dipping the papers in a solution of $0 \cdot 1 \%$ ninhydrin in acetone containing $1 \%(\mathrm{w} / \mathrm{v})$ of $2: 4: 6:$-collidine and then heating at $60^{\circ}$ for $15 \mathrm{~min}$. After storing these papers in the dark overnight, the presence of 2-oxoglutarate was revealed as a spot which fluoresced in the light of a mercury vapour lamp (Rabson \& Tolbert, 1958). Oxaloacetate could not be distinguished from pyruvate by this method.

Chromatographic identification of an unknown compound was presumed when (i) both the unknown and an authentic sample had the same chromatographic mobilities in both solvents; (ii) one spot of appropriately increased size and intensity was obtained when the unknown was chromatographed in the presence of authentic sample.

\section{RESULTS}

\section{Transaminase activities}

The ability of cell extracts of acetic acid bacteria to effect reversible transaminations in the following systems was tested:

(a) L-glutamate + oxaloacetate $\rightleftharpoons 2$-oxoglutarate + L-aspartate;

(b) L-glutamate + pyruvate $\rightleftharpoons 2$-oxoglutarate +L-alanine;

(c) $\mathrm{L}$-aspartate + pyruvate $\rightleftharpoons$ oxaloacetate $+\mathrm{L}$-alanine.

The results (Table 1 ) showed that, in $3 \mathrm{hr}$., extracts of all lactaphiles effected reversible transamination as in (i). By contrast, extracts of glycophiles showed an undetectable effect (Acetobacter gluconicum) or only a small effect ( $A$. capsulatum, $A$. turbidans, $A$. viscosum), the amount of transamination brought about even when incubation was prolonged for $24 \mathrm{hr}$. being much less than that brought about by the lactaphiles in $3 \mathrm{hr}$. There was no clear evidence of transaminations proceeding as in 
$(b)$ and $(c)$ at $\mathrm{pH}$ values between 5.6 and 9.0 In those cases (Acetobacter acidummucosum, $A$. rancens, $A$. oxydans) where more than traces of $\alpha$-alanine were produced from aspartate and pyruvate, the reverse formation of aspartate from oxaloacetate and $\alpha$-alanine did not occur, and $\alpha$-alanine was formed from aspartate even in the absence of added pyruvate. This indicated that $\alpha$-alanine formation from aspartate involved a mechanism other than transamination, possibly $\beta$-decarboxylation (see below).

\section{Table 1. Transaminative abilities of cell extracts of acetic acid bacteria}

Reaction mixtures ( $1 \mathrm{ml}$.) contained cell extract (equiv. $85 \mu \mathrm{g}$. total-N) and substrate solution at pH 7.3. Substrate solutions contained $20 \mu$ mole of L-glutamate or L-aspartate or $40 \mu$ mole of DL-alanine alone or in admixture with $20 \mu$ mole of oxaloacetate, 2-oxoglutarate or pyruvate. Transformation products (amino acid, 2-oxoglutarate) were detected by paper chromatography of samples ( $80 \mu \mathrm{l}$.) withdrawn after $8 \mathrm{hr}$. incubation at $28^{\circ}$.

Acetobacter spp.

Lactaphiles:

A. acidum-mucosum

A. mobile

A. racens

A. ascendens

A. oxydans

Glycophiles:

A. capsulatum

A. gluconicum

A. turbidans

A. viscosum
Ninhydrin-reacting substances produced from

$\begin{array}{cccccc}\text { glu } & \text { asp } & \text { glu } & \text { ala } & \text { asp } & \text { ala } \\ + & + & + & + & + & +\end{array}$

(ala)

asp glu

(ala) (ala)

asp glu

(ala)

asp glu

ogl (ala)

(ala)

asp

glu

(ala)

nil

$$
\text { nil }
$$

nil

(ala)

ala

nil

ala nil

ala

$\begin{array}{ccccccc}\text { (asp) } & \text { (glu) } & \text { nil } & \text { nil } & \text { nil } & \text { nil } & \text { nil } \\ \text { nil } & \text { nil } & \text { nil } & \text { nil } & \text { nil } & \text { nil } & \text { nil } \\ \text { (asp) } & \text { (glu) } & \text { nil } & \text { nil } & \text { nil } & \text { nil } & \text { nil } \\ \text { (asp) } & \text { (glu) } & \text { (ala) } & \text { nil } & \text { nil } & \text { nil } & \text { nil }\end{array}$

ala, $\alpha$-alanine; asp, aspartate; glu, glutamate; oac, oxaloacetate; ogl, oxoglutarate; pyr, pyruvate, ( ) indicates trace amounts.

With glutamate + oxaloacetate as substrate in a system catalysed by an extract of Acetobacter mobile, chromatography showed that aspartate formation occurred within the range of $\mathrm{pH} 5 \cdot 3-7 \cdot 8$. At $\mathrm{pH} 7 \cdot 3$ (approximately the optimum) transamination occurred readily at temperatures from $21-28^{\circ}$ : there was only a little action in $4 \mathrm{hr}$. at $37^{\circ}$ and none at $47^{\circ}$.

Simple dialysis of the 'soluble enzyme' preparation from Acetobacter mobile for $50 \mathrm{hr}$. at $2^{\circ}$ against $0.01 \mathrm{M}$-phosphate buffer $(\mathrm{pH} \mathrm{7 \cdot 3})$ failed to inactivate the preparation catalysing system (i). However, its capacity to effect this reversible transamination was greatly diminished by ultrafiltration(Grant, Rowe \& Stanworth, 1958). The enzyme thus treated was reactivated by addition of the dialysate or of $1.7 \mu \mathrm{g}$. pyridoxal phosphate $/ \mathrm{ml}$. When stored at $-15^{\circ}$, cell extracts at $\mathrm{pH} 7$ retained their transaminative ability substantially undiminished for periods of many months. 


\title{
Aspartate $\beta$-decarboxylase activities
}

The formation from L-aspartate of appreciable quantities of a ninhydrin-reacting material having the chromatographic mobility of $\alpha$-alanine indicated that cell extracts of the lactaphiles possessed an aspartate decarboxylase. Of the glycophiles, only Acetobacter viscosum possessed this system, and that only to a small extent.

Freshly prepared cell extracts of Acetobacter acidum-mucosum, which were particularly potent in ability to attack aspartate, were selected for further study. Manometric measurements (Table 2) showed that such extracts released an alkalisoluble gas from L-aspartate solutions at $\mathrm{pH} \mathrm{5 \cdot 2.} \mathrm{The} \mathrm{evolution} \mathrm{of} \mathrm{gas} \mathrm{was} \mathrm{approxi-}$ mately linear over a period from 5-20 min., when the amount of gas evolved was nearly $70 \%$ of that theoretically obtainable from the aspartate added. After standing at laboratory temperature for a further hour, the reaction mixtures in the Warburg vessels were examined by paper chromatography. The ethanol + ammonia + water solvent in particular permitted adequate resolution of aspartate, $\alpha$-alanine

\section{Table 2. Decarboxylation of L-aspartate by cell extracts of Acetobacter acidum-mucosum}

\begin{abstract}
Each Warburg vessel contained $8 \mathrm{ml}$. total volume. Complete reaction mixtures contained L-aspartic acid, adjusted to pH 5.2 (8 $\mu$ mole); acetate buffer, pH 5.2 (0.3 m-mole); and enzyme (1.6 mg. protein, added from side-arm). The centre well contained $0.2 \mathrm{ml}$. $20 \%$ KOH only where indicated. Under the conditions used, the yield of $\mathrm{CO}_{2}$ theoretically obtainable by $\beta$-decarboxylation of $8 \mu$ mole L-aspartate was $195 \mu \mathrm{l}$.
\end{abstract}

$\mu \mathrm{l} . \mathrm{CO}_{2}$ evolved at $25^{\circ}$ in

$\quad$ Reaction mixture
No enzyme
No aspartate
Complete
Complete (KOH in centre well)

$\begin{array}{rccc}5 \text { min. } & 10 \text { min. } & 15 \text { min. } & 20 \text { min. } \\ 6 & 8 & 8 & 8 \\ 7 & 8 & 9 & 10 \\ 20 & 60 & 97 & 184 \\ 9 & 9 & 9 & 9\end{array}$

and $\beta$-alanine, which were also distinct in colour of their ninhydrin compounds $(\alpha$-alanine, purple; $\beta$-alanine, blue) after runs in this solvent. The results showed that (i) virtually all the aspartate had disappeared from the reaction mixtures containing initially both enzyme and aspartate; (ii) a spot of appropriately increased size was obtained when the reaction mixture was supplemented with $\alpha$-alanine, whereas supplementation with $\beta$-alanine gave a second spot, distinct in mobility in both solvents and in colour in the ethanol + ammonia + water solvent; (iii) the cell extract alone contributed no appreciable quantities of amino acids to the reaction mixtures. Thus, cell extracts of Acetobacter acidum-mucosum catalysed the $\beta$-decarboxylation of $\mathrm{L}$-aspartate to $\alpha$-alanine; $\beta$-alanine, the product of $\alpha$-decarboxylation, was not produced. The aspartate $\beta$-decarboxylase activity of cell extracts of $A$. acidum-mucosum was retained on storage at $-15^{\circ}$ for at least one month.

\section{Oxidation of organic acids}

Oxidation of organic acids was studied manometrically with whole organisms. On adding substrate from the side-arm, little or no oxygen was absorbed during the first 5-10 min., but thereafter there was a linear rate of oxygen uptake from which $\mathbf{Q}_{\mathbf{O}_{2}}$ values were calculated. The results (Table $\mathbf{3}$ ) show that the lactaphiles had 
greater general ability to oxidize organic acids than had the glycophiles, the oxidative abilities of which were restricted mainly to lactate, pyruvate and oxaloacetate, and were relatively feeble or lacking with respect to all other substrates. In a few cases, restricted entirely to the lactaphiles, appreciable stimulations of oxygen uptake were recorded when a mixture of $0.03 \mu$ mole of each of the following was added to the main substrate undergoing oxidation in the Warburg vessel: citric, isocitric, cis-aconitic, 2-oxoglutaric, succinic, fumaric, malic and oxaloacetic acids.

\title{
Table 3. Oxidative abilities of roashed suspension of acetic acid bacteria acting on organic acids
}

\begin{abstract}
Warburg vessels contained in $2 \cdot 2 \mathrm{ml}$. final volume: washed organisms equiv. $0.2-0.3 \mathrm{mg}$. dry wt.; phosphate buffer (pH 5.8; $50 \mu$ mole); substrate (pH 5.8; $100 \mu$ mole added from side-arm); $0.2 \mathrm{ml}$. $20 \%$ KOH (centre well). Temperature $35^{\circ}$. The values have been corrected for oxygen uptake in the absence of the major substrate. Values in parentheses indicate oxygen uptakes in the presence of 'sparker' amounts of mixed TCA cycle intermediates in those cases where oxidation was appreciably stimulated.
\end{abstract}

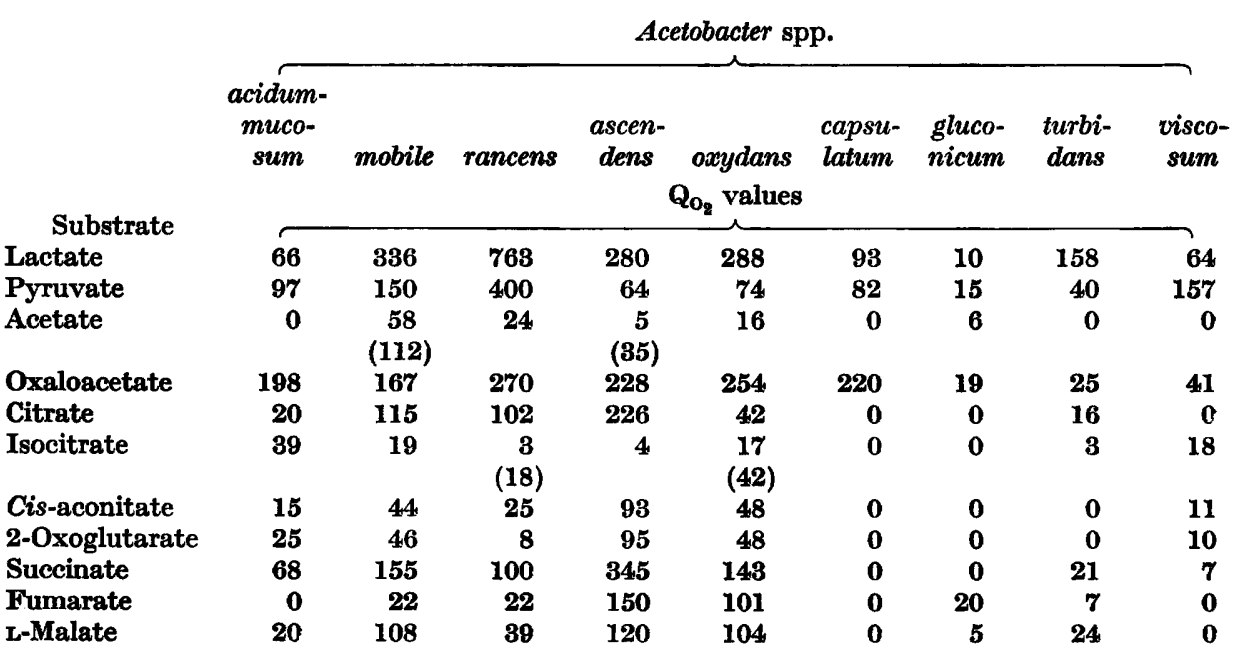

Citrogenase activities

The general ability of lactaphiles, but not of glycophiles, to oxidize intermediates of the tricarboxylic acid (TCA) cycle indicates that a TCA cycle may operate in lactaphiles but not in glycophiles. This suggestion was already implicit in the work of Brown \& Rainbow (1956), who showed that lactaphiles, but not glycophiles, could grow on acetate and corresponded to Vaughn's (1942) 'over-oxidizers', which oxidized acetate to $\mathrm{CO}_{2}$ and water. It seemed therefore desirable to examine acetobacters for citrogenase, the enzyme which enables acetate to enter the TCA cycle. The results (Table 4) showed that extracts from each of the lactaphiles catalysed the synthesis of citrate from acetyl phosphate and oxaloacetate. Extracts of the glycophiles apparently did not, the blank readings being greater than those given by the test reaction mixtures. There is reason to believe that this effect resulted from enzymic decarboxylation of oxalaocetate, which is the constituent mainly responsible for the colour developed in the blanks in the reaction applied to determine citrate. Although oxaloacetic decarboxylase activity could be detected 
in extracts of glycophilic and lactaphilic organisms (P. J. le B. Williams, unpublished observations), its effect on the citrate colour reaction, detectable in the absence of appreciable citrate synthesis, would be swamped in the citrogenase tests involving extracts of lactaphilic cells, in which considerable citrate synthesis takes place.

\section{Table 4. Citrogenase activities of cell extracts of acetic acid bacteria}

Reaction mixtures (3 ml. at pH $\mathbf{7 \cdot 4})$ contained extracts of Acetobacter spp. and Escherichia coli ATCC 4157 ( 1 ml. of each in 0.1 M-phosphate buffer, pH 7.4); and $1 \mathrm{ml}$. of a solution ( $\mathrm{pH} 7 \cdot 4$ ) containing lithium acetyl phosphate $(50 \mu \mathrm{mole})$, oxaloacetic acid (100 $\mu$ mole) and L-cysteine ( $50 \mu$ mole). Citrate produced was determined colorimetrically after $90 \mathrm{~min}$. incubation at $28^{\circ}$ : the values are corrected for the appropriate blank determinations on reaction mixtures from which the Acetobacter extract was omitted and they are the mean values of three determinations.

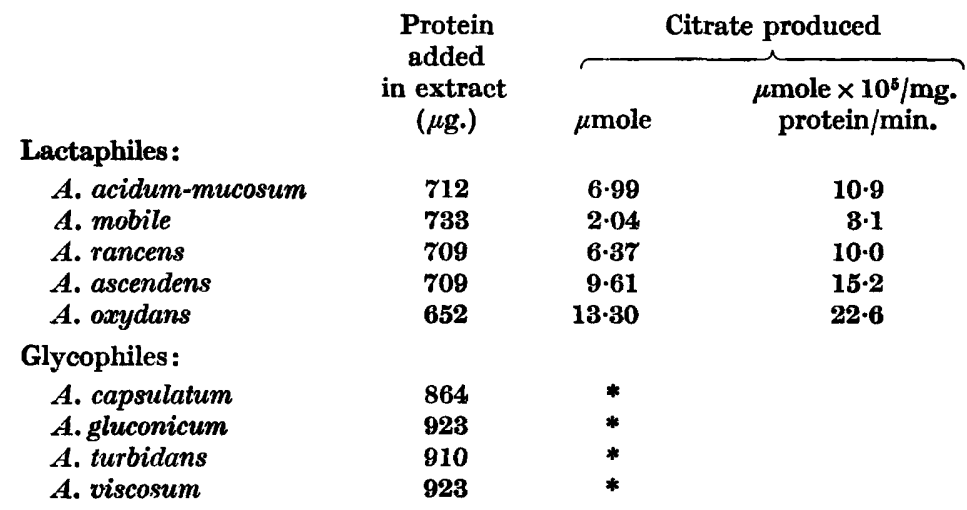

* Colorimetric readings were all about $15 \%$ lower than those of the corresponding blanks: see text.

\section{DISCUSSION}

The results presented indicate that the two groups already recognized within the genus Acetobacter mainly on nutritional grounds (Rainbow \& Mitson, 1953; Brown \& Rainbow, 1956) are also metabolically distinct. Evidence from other sources is accumulating to show that the genus Acetobacter, as at present constituted, contains two groups meriting generic distinction. Thus, on morphological and biochemical criteria, Leifson (1954) proposed the recognition of the genera Acetobacter and Acetomonas. This proposal is supported by the work of Shimwell (1958, 1959) and of Asai \& Shoda (1958), although the Japanese workers prefer the name Gluconobacter to Acetomonas. Previous papers from this laboratory (Rainbow \& Mitson, 1953; Brown \& Rainbow, 1956) drew attention to the close correspondence, respectively, between our lactaphiles and glycophiles on the one hand, and the proposed genera Acetobacter and Acetomonas (or Gluconobacter) on the other. In so far as results obtained with relatively few strains will permit generalizations to be drawn, the present findings support the proposed new subdivision of the acetic acid bacteria into two genera with distinct metabolic patterns.

As a group, the glycophiles appear to be enzymically less well equipped than the lactaphiles, which are less exacting in their growth requirements and in their abilities to transaminate and to oxidize organic acids. This oxidative ability of lactaphilic strains may reflect a functional TCA cycle. The detection of citrogenase in their cell extracts is consistent with this hypothesis. The general inability of 
glycophilic organisms to oxidize intermediates of the TCA cycle and the absence from them of appreciable citrogenase activity is an indication that in this group the TCA cycle is unlikely to function. It is noteworthy that a strain of Acetobacter suboxydans, the description of which shows it to be a glycophile by our criteria, is reported to lack the TCA cycle (King \& Cheldelin, 1952).

Possibly the oxidative and transaminative abilities of lactaphiles are related metabolic phenomena. If the TCA cycle operates in them, the synthesis of the key amino acids, glutamate and aspartate, could take place by transamination from the corresponding keto acids generated by the cycle. This possibility is denied to the glycophiles, which fail to grow on glucose + salts + ammonia medium, but do grow when glutamate is substituted for ammonia, or when ammonia and 2-oxoglutarate are supplied together (Brown \& Rainbow, 1956). The key deficiency of glycophilic organisms thus seems to be inability to synthesize 2-oxoglutarate.

Whereas lactaphilic organisms differ from glycophilic organisms in possessing greater ability to transaminate reversibly between glutamate and aspartate, both types of organism lack the ability to form $\alpha$-alanine from glutamate or aspartate by transamination. However, by virtue of their aspartate $\beta$-decarboxylase system, lactaphiles can synthesize $\alpha$-alanine from glutamate in two stages involving transamination to aspartate followed by enzymic $\beta$-decarboxylation. The latter process seems not to have been reported in aerobic bacteria, although the enzyme is present in Clostridium relchii (Meister, Sober \& Tice, 1951). Our findings provide little indication of the mechanisms by which glycophilic organisms synthesize aspartate and $\alpha$-alanine.

\section{REFERENCES}

Asar, R. \& Shoda, K. (1958). The taxonomy of Acetobacter and allied oxidative bacteria. J. gen. appl. Microbiol. Japan 4, 289.

Brown, G. D. \& RaInBow, C. (1956). Nutritional patterns in acetic acid bacteria. J. gen. Microbiol. 15, 61.

Grant, G. H., Rowe, D. S. \& Stanworth, D. R. (1958). The concentration of protein solutions by ultrafiltration through dialysis tubing. Biochem. J. 69, $13 P$.

KING, T. E. \& CheLdelin, V. H. (1952). Oxidative dissimilation in Acetobacter suboxydans. J. biol. Chem. 198, 127.

Leifson, E. (1954). The flagellation and taxonomy of species of Acetobacter. Antonie van Leeuwenhoek J. Microbiol. Serol. 20, 102.

Lowry, O. H., Rosebrough, N. J., FARR, A. L. \& RaNdaII, R. J. (1951). Protein measurement with the Folin phenol reagent. J. biol. Chem. 193, 265.

Macdonald, R. E. \& Waterbuny, W. E. (1959). Colorimetric estimation of citric acid. Nature, Lond. 184, 988.

Meister, A., Sober, H. A. \& Tice, S. V. (1951). Enzymic decarboxylation of aspartic acid to $\alpha$-alanine. J. biol. Chem. 189, $57 \%$.

OChoA, S., Stern, J. R. \& Schneider, M. C. (1951). Enzymic synthesis of citric acid. 11. Crystalline condensing enzyme. J. biol. Chem. 193, 691.

Rabson, R. \& Tolbert, N. E. (1958). Detection of $\alpha$-ketoglutaric acid and other ketoacids on paper chromatograms with ninhydrin. Nature, Lond. 181, 50.

Rarnbow, C. \& Mrtson, G. W. (1953). Nutritional requirements of acetic acid bacteria. J. gen. Microbiol. 9, 371.

SHImweld, J. L. (1958). Flagellation and taxonomy of Acetobacter and Acetomonas. Antonie van Leeurvenhoek J. Microbiol. Serol. 24, 187.

Shimwell, J. L. (1959). The genus Acetomonas. Antonie van Leeurvenhoek J. Microbiol. Serol. 25, 353.

VAUGHAN, R. H. (1942). The acetic acid bacteria. Wallerstein Labs. Commun. 5, 5. 